\title{
日本臨床麻酔学会第29回大会シンポジウム
}

DAMの現状総括と今後の方向性を探る

\section{DAM とラリンジアルマスクェアウェイ}

\begin{abstract}
[要旨] 気道管理はマスク換気と気管挿管を中心に発展した. LMA(Laryngeal Mask Airway)が世の中に出て四半世紀が過ぎ, LMAはDAM(Difficult Airway Management)に必要不可欠となった. 当初, LMAの開発は気管挿管より簡便かつ 低侵襲という特徵を目的としていた。 しかし, 気道確保困難に有効という症例報告や 臨床研究の増加に伴いDAMでの役割が広く認められるようになった. そして, LMAの3つの特徵が明らかになるに伴い, 初期の LMA Classicから発展した挿管 用LMAやLMA ProSeal といった第2世代，そして第3世代のLMA Supremeへ と進化している.

キーワード：気道確保困難, ラリンジアルマスク, 種類, プロシール, スプリーム
\end{abstract}

（日臨麻会誌Vol.30 No.4, $577 ＼mathrm{~ 584, ~ 2010) ~}$

\section{I＼cjkstart気道管理の発展とLMA}

気道管理はマスク換気と気管挿管を2つの柱とし て発展してきた。そのなかでマスク換気困難・気管 挿管困難の処置として, DAM (Difficult Airway Management）の概念も発達した。後に, LMA (Laryngeal Mask Airway)がこのなかに加わるこ ととなるが, LMAが世の中に登場するのは今から 四半世紀前の 1983 年になる ${ }^{1)}$.

British Journal of Anaesthesiaにはじめて載った LMAの臨床報告では, 歯科用の黒い鼻マスクに気 管チューブを取り付けたプロトタイプを用い (図 1)，23症例で全身麻酔が行われている ${ }^{1)}$ 。そも そも，発案者のDr. Brain は気管挿管よりも実用的 で，かつ侵襲性が低い気道管理手段の開発を考えて *新日鐵広畑病院麻酔科
いた ${ }^{2)}$. 目的として，喉頭鏡や筋弛緩薬は必要なく 簡便であり，気管抻管ほど血圧の上昇や頻脈は認め ず低侵襲であることがあげられる ${ }^{3)}$ 。このように， 簡便性と低侵襲性が目的とされたLMA(図2)は, はじめて報告された 23 症例の全例で問題なく気道 が確保されている。また，これらのなかには巨大な 下顎腫瘤で挿管困難が予想された患者が含まれてお り, この時点でLMAの気道確保困難症例での有効 性も示唆されていた。その後も, 気道確保困難症例 での有効性が多数報告されることになる(4),5)。すで にこの時期にはLMAの3つの特徵である，(1)簡便 性，(2)低侵襲性，(3)気道確保困難での有効性，の輪 郭が形作られていたといえよう。

シリコン製のマスクをもつ量産型タイプ(図3)が 1988年に臨床使用されると，1990年には発売元で 


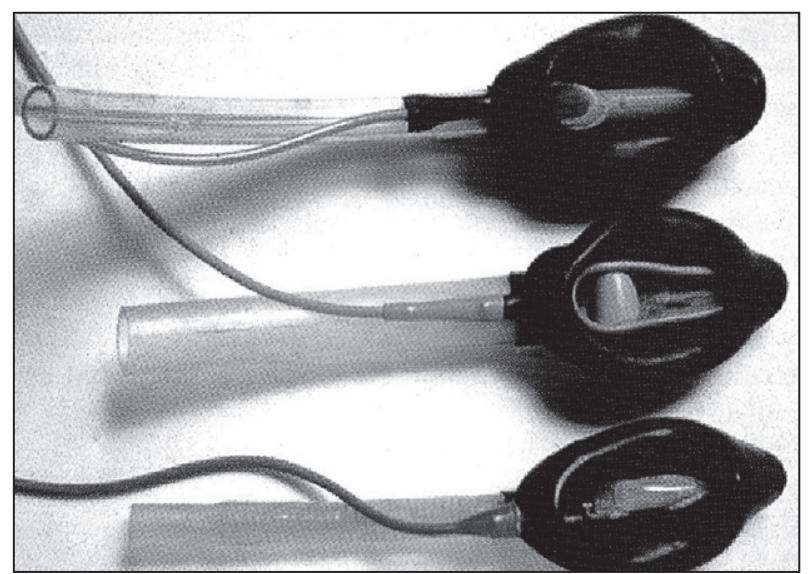

図1 プロトタイプ

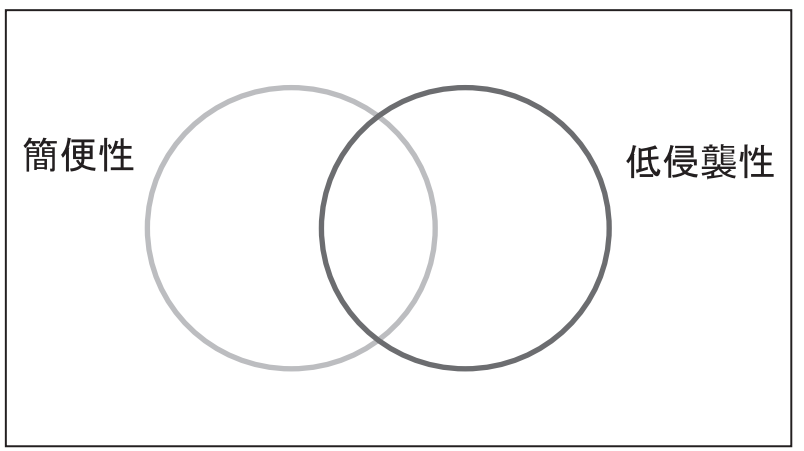

図2 LMAの特徵(挿管と比較)

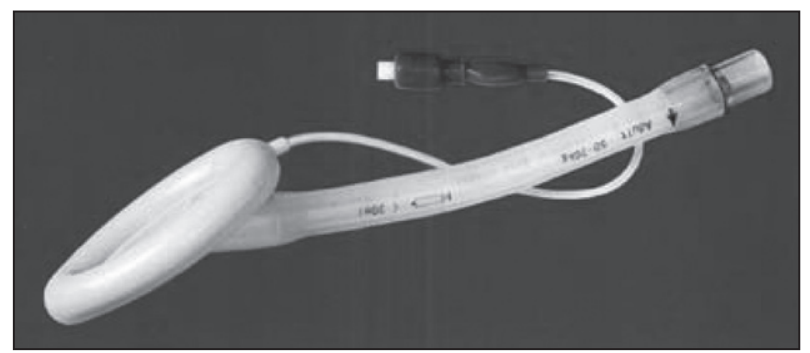

図３シリコン量産型

ある英国のすべての手術室に納品され，1992年に は日本でも使用されることとなった ${ }^{6)}$ 。その後, 世 界中へと広まっていく。この量産型は現在も LMA Classic として入手可能である.

\section{DAM ガイドラインにおける LMA}

1990年代初頭は DAM に関して一定のガイドライ
ンを作成する動きが本格化する時期でもある7). 1993 年に米国麻酔科学会 (ASA)からフローチャー ト形式のアルゴリズムが発表され，マスク換気困難 でかつ挿管困難な場合 (cannot intubate, cannot ventilate:CICV)の換気手段としてコンビチューブ, TTJV (transtracheal jet ventilation, 経気管ジェッ 卜換気)そしてLMAが組み込まれている $\left(\right.$ 図4) ${ }^{8}$. 同時に，世界中で臨床使用されているLMAが気道 確保困難症例で有効であったという報告がさらに増 えてくる。これに応える形で, 1996年にはアルゴ リズムでLMAが役立つ部位が詳しく報告され， LMA は換気手段だけでなく挿管手段としても有効 と位置づけられる ${ }^{9)}$.さらに1993年のアルゴリズム を改定した新しい2003年版では LMA は CICVの第 一選択となり，また抻管手段としてもフローチャー トに組み込まれるに至った $(\text { 図 5 })^{10)}$.

気道確保困難対策ガイドラインでASA 以外に有 名である英国の気道確保困難学会 (Difficult Airway Society：DAS)のガイドラインは2004年に発表さ

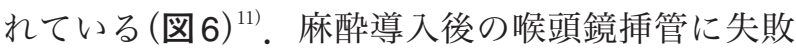
した際の次の挿管手段として，LMAまたは扱管用 LMAが登場する(Plan B)。そのほかにも，挿管失 敗後にマスク換気も困難となり CICVに陥った場合 の換気手段としてLMAは位置づけられている (Plan D).

このほかにも各国から出されている気道確保困難 対策のガイドラインにはLMAが抻管手段または換 気手段として位置づけられている ${ }^{12)}$ 。この経緯から， (1)簡便性，(2)低侵襲性，というLMAの特徵に，(3) 気道確保困難での有効性，が加わり 3 つの柱が確立 したといえよう (図 7 $)^{13)}$.

\section{LMAの発展}

LMA Classic に続いて，LMA Flexible(1992年), LMA Fastrach(1997年), LMA Unique(1998年), LMA ProSeal(2000年)がそれぞれ発売された ${ }^{6}$ 。

LMA FlexibleはLMA Classic と同じマスクをも 


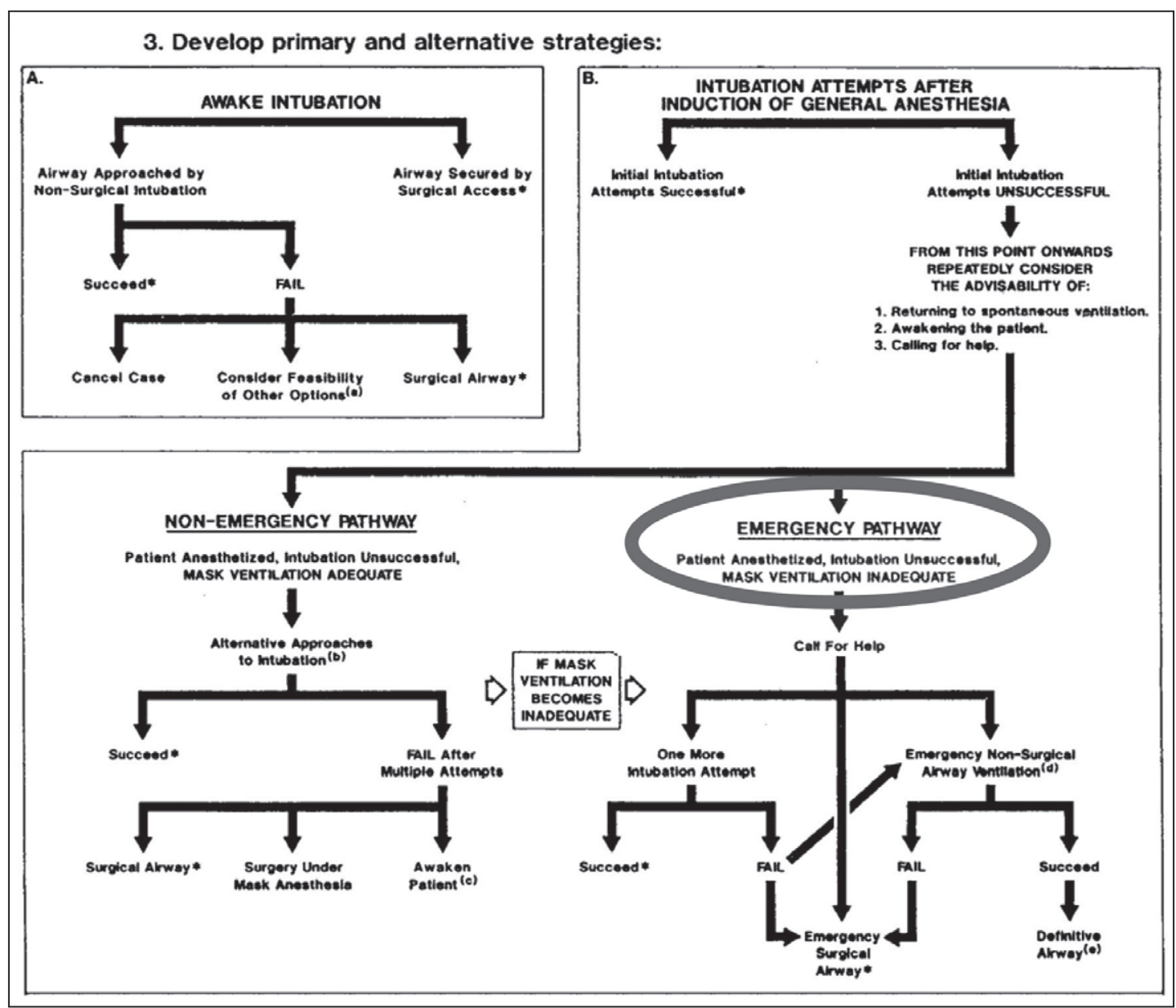

図4 1993 ASA Practice Guideline

CICVでは combitube, TTJV, LMAのどれかを選択.

〔文献 8)より引用・改変〕

つが，エアウェイチューブはらせん入りで柔軟に曲 がると同時にチューブの閉塞が起こりにくい構造と なっている $\left(\right.$ 図8 ${ }^{14)}$. そのほか, チューブはLMA Classicよりも細くて長いために口腔内手術でも術 野を妨げないよう配慮されている ${ }^{6)}$ 。柔軟なチュー ブは，挿入後には術野を妨げない位置に固定できて 便利であるが，柔軟なチューブだからこそ挿入は難 しくなった，標準挿入法を正確に行えば多くの症例 の挿入は問題なく行うことが可能であるが，その他 の挿入法では困難な場合も多い。このため, LMA Flexibleの挿入補助だけを目的とした鉗子も発売さ れている。頭頝部や口腔内の手術が適応で，簡便性
や低侵襲性が主な特徵である。しかし，挿入はいく ぶん難しく，LMAを介した気管挿管も LMA Classicより制限されることから，気道確保困難に対す る有効性という特徵は少なくなっている.

LMA Unique は基本的な形状は LMA Classic と 同じである $\left(\right.$ 図9 ${ }^{15)}$ 。しかし，ディスポーザブル製 品であるため両者の素材は異なっている。 LMA Classicはマスクがシリコン製であったが，LMA Unique はマスクとチューブがポリ塩化ビニル製で ある.ポリ塩化ビニル製の方が硬い印象を受けるが,

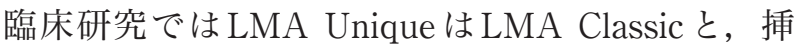
入の難易度，シール圧などで差はみられていな 


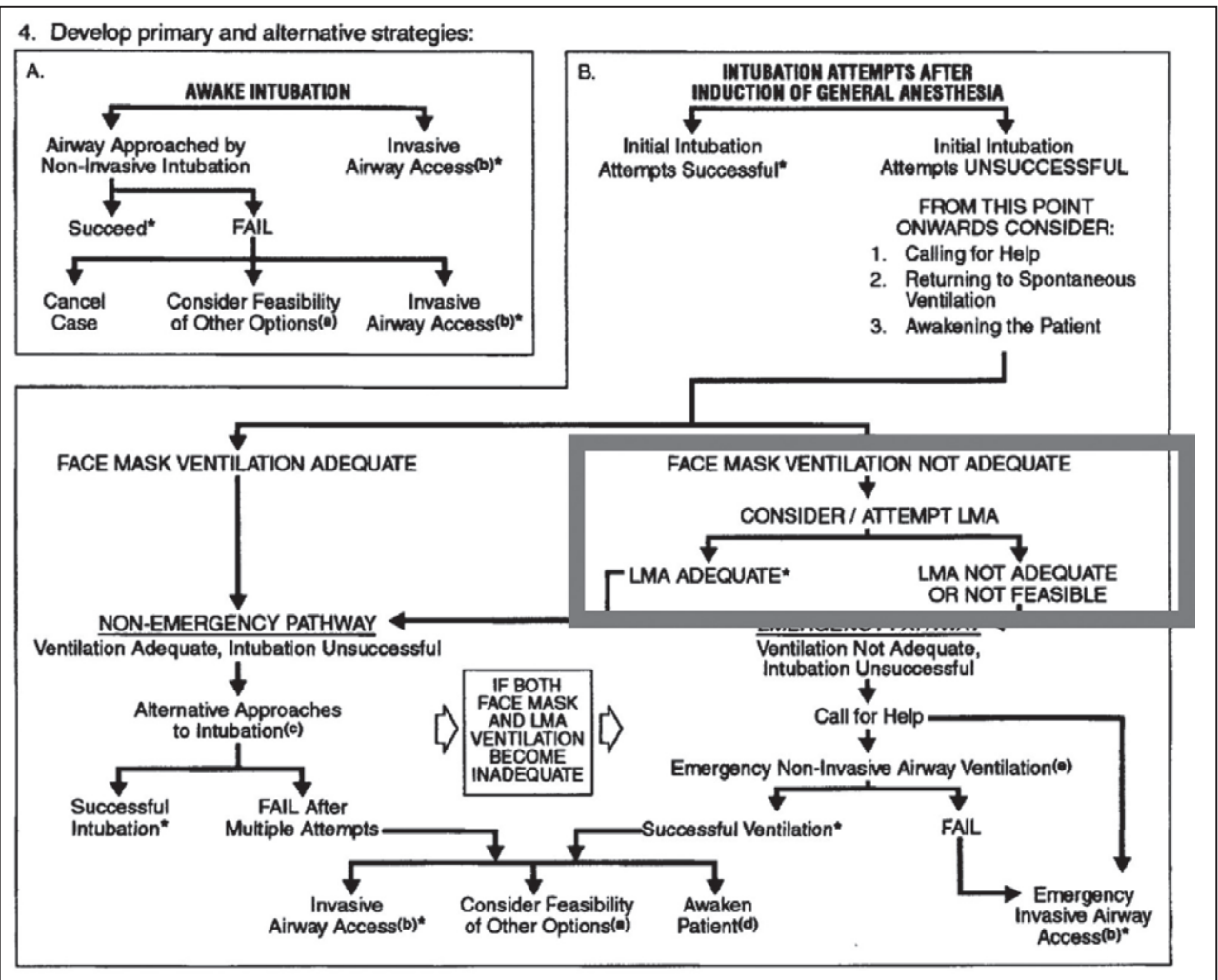

図5 2003 Updated Practice Guideline

LMA は CICV の第一選択となる.

〔文献 10）より引用・改変〕

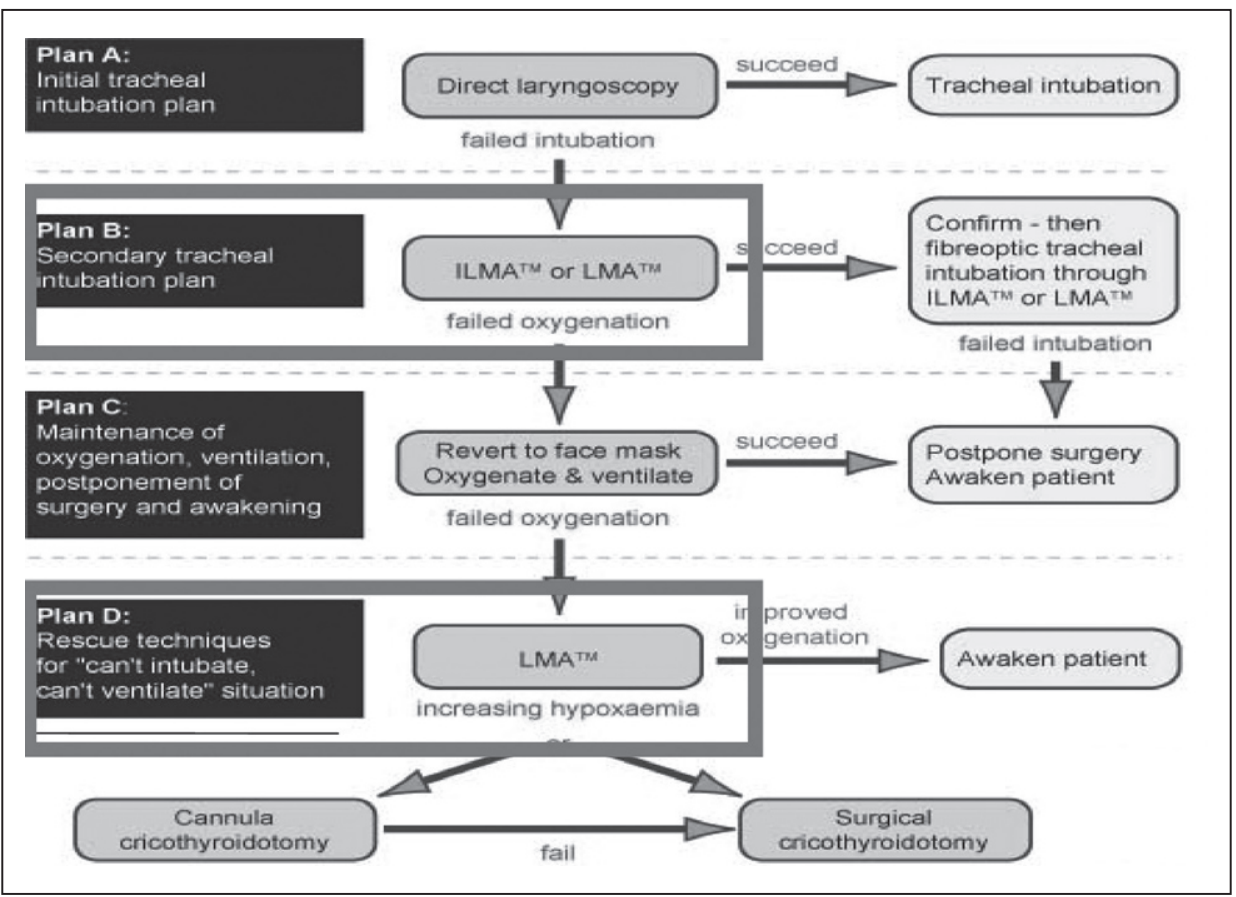

図6 Difficult Airway Society guideline 
い ${ }^{15)}$. 滅菌されたディスポーザブル製品のため, 消 毒等の手間がなく, 救急領域での使用にも適してい る。この点から, 気道確保困難に対する有効性は強 調されたといえるだろう。

LMA Fastrach は挿管を目的としたLMAで, LMA Classic と大きく構造が変わった ${ }^{16)}$. エアウエ イチューブは短くL字状に曲がった金属性である。 硬いチューブにより挿入は簡単になった。また，八 ンドルがエアウェイチューブに付いたため挿入時に 指を患者の口腔内に入れる必要がなく, 挿入後のマ スクの位置調整が可能である(図 10)。そのほかに も，LMA Classicではマスク開口部にあった 2 本の バーがなくなり, 代わりに 1 本の幅広い喉頭蓋挙上 バーに変更されている。このバーは一方のみの固定 であるため可動性があり，挿管時には気管チューブ がマスク開口部を通る際に，妨げない構造になって いる ${ }^{16)}$.

LMA ProSeal はLMA Classic とは違うマスクと チューブをもち，マスクは深く柔軟になったととも に，背面にも付けられた第2のカフから LMA Classicより高いシール圧が得られる ${ }^{17)}$. チューブは換 気用のほかにも第 2 のューブがあり, 胃内容のド レナージが可能となった(図11)。LMA Classicの 弱点であった低いシール圧と胃内容逆流に対策がと られ，簡便性と低侵襲性という特徵がより進歩した といえる。逆に, LMA ProSealを介しての抻管は LMA Classic を使うよりも手間がかかるといえ，挿 管器具としての特徵は薄れている.

これらの 5 種類の LMA は，マスクの形状が同じ LMA Classic, LMA Flexible, LMA Unique は第 1 世代, LMA Classic を挿管器具(intubator) として 改良したLMA Fastrach, 簡便で低侵襲な気道確保 器具(airway)として改良したLMA ProSealは第2 世代といえるだろう。

これらだけでなく，新しいLMAも使用可能とな りつつある. LMA Supremeはディスポーザブル製 品でありながら, 深いマスクとドレインチューブを

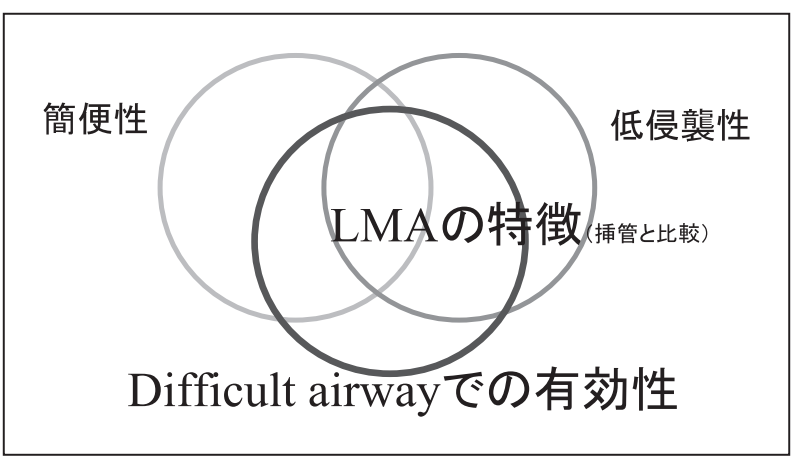

図7 LMAの特徵 (挿管と比較)

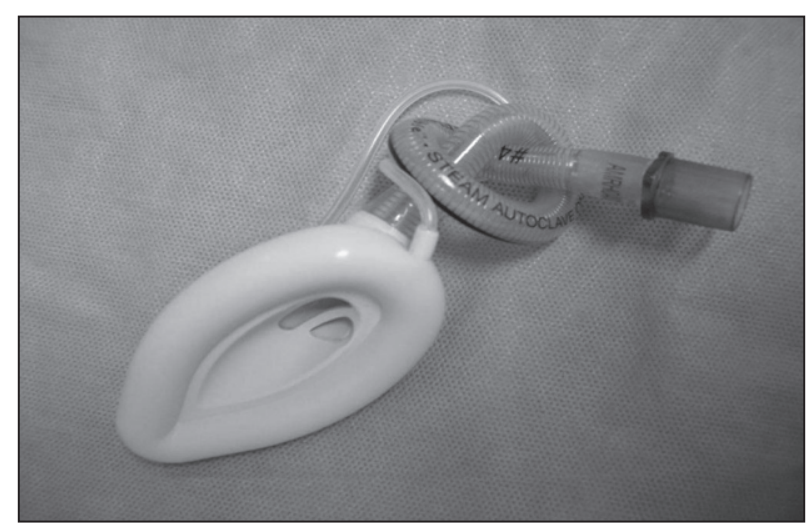

図8 Flexible(1992)

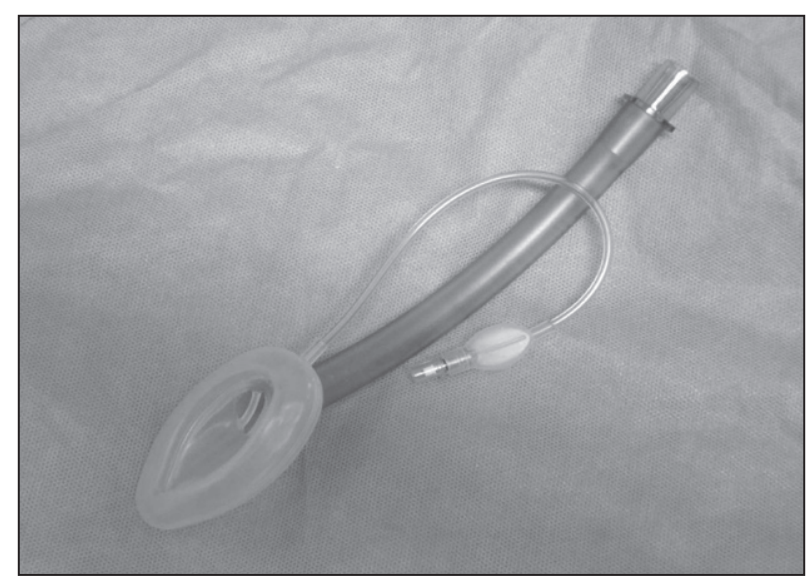

図9 Unique(1998)

もち，LMA ProSealのように高いシール圧と胃内 容のドレナージを目指した製品である ${ }^{18)}$ ．また，工 アウェイチューブはL字型で硬くなると同時に短い ハンドル付きで，LMA Fastrachのように挿入も簡 


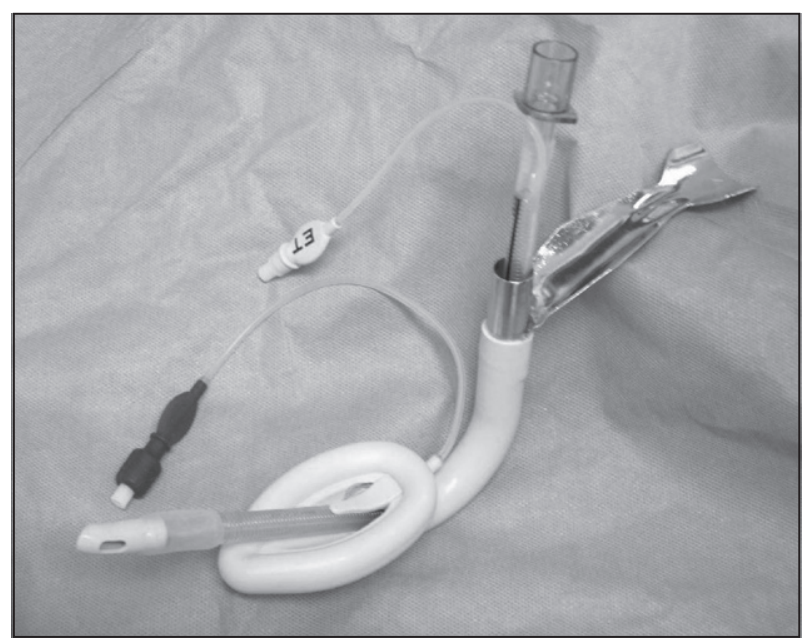

図10 Fastrach (1997)

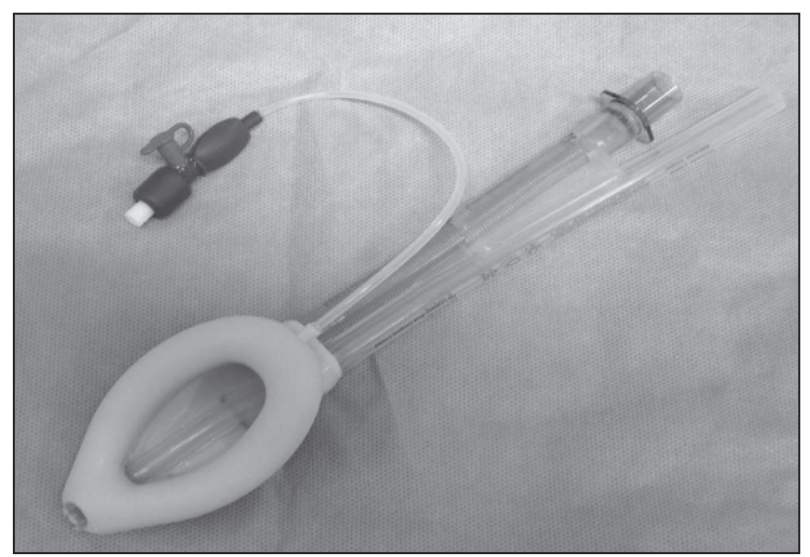

図 11 ProSeal(2000)

単となった(図12)。つまりLMA Supremeは第2 世代の LMA である LMA ProSeal と LMA Fastrach の両方のメリットを一つに組み込んだ第 3 世代の LMA と考えられる.

日本ではまだ発売されていないLMA CTrachは, LMA Fastrachにカメラとカラーモニターを組み込 むことで，插管チューブの声門通過が視覚的に確認 できる $(\text { 図 13 })^{19)}$.これも第 2 世代のLMAである LMA Fastrachをさらに発展させた第 3 世代の LMA といえるだろう。

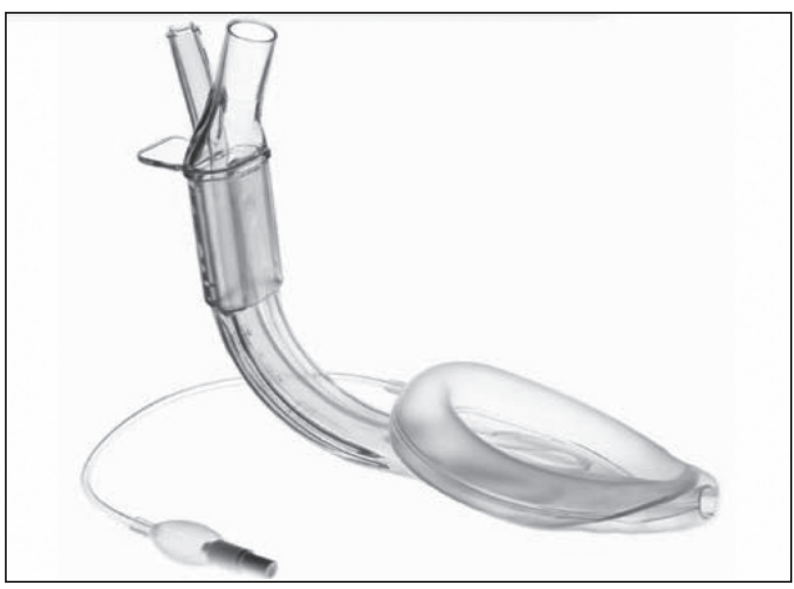

图 12 Supreme (2007)

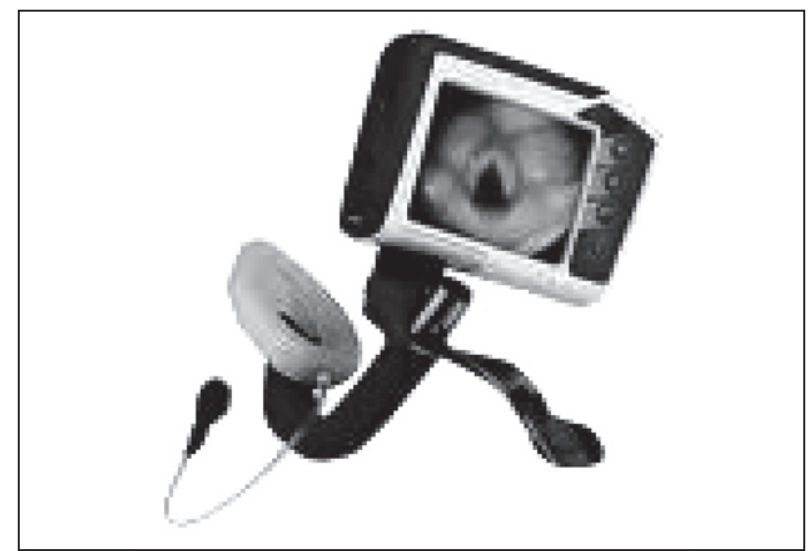

図 13 CTrach (2005)

\section{おわりに}

このようにLMAは気道確保器具 (airway) と抻管 器具(intubator) との両方の特徵をもちながら，そ れぞれに発展してきた(図14)。その間の役割変化 を知ることで，現在の気道管理をより深く理解する ことができるだろう。

\section{参考文献}

1) Brain AI : The laryngeal mask--a new concept in airway management. Br J Anaesth 55 : 801-805, 1983

2) Brain AI : The development of the Laryngeal Mask--a 


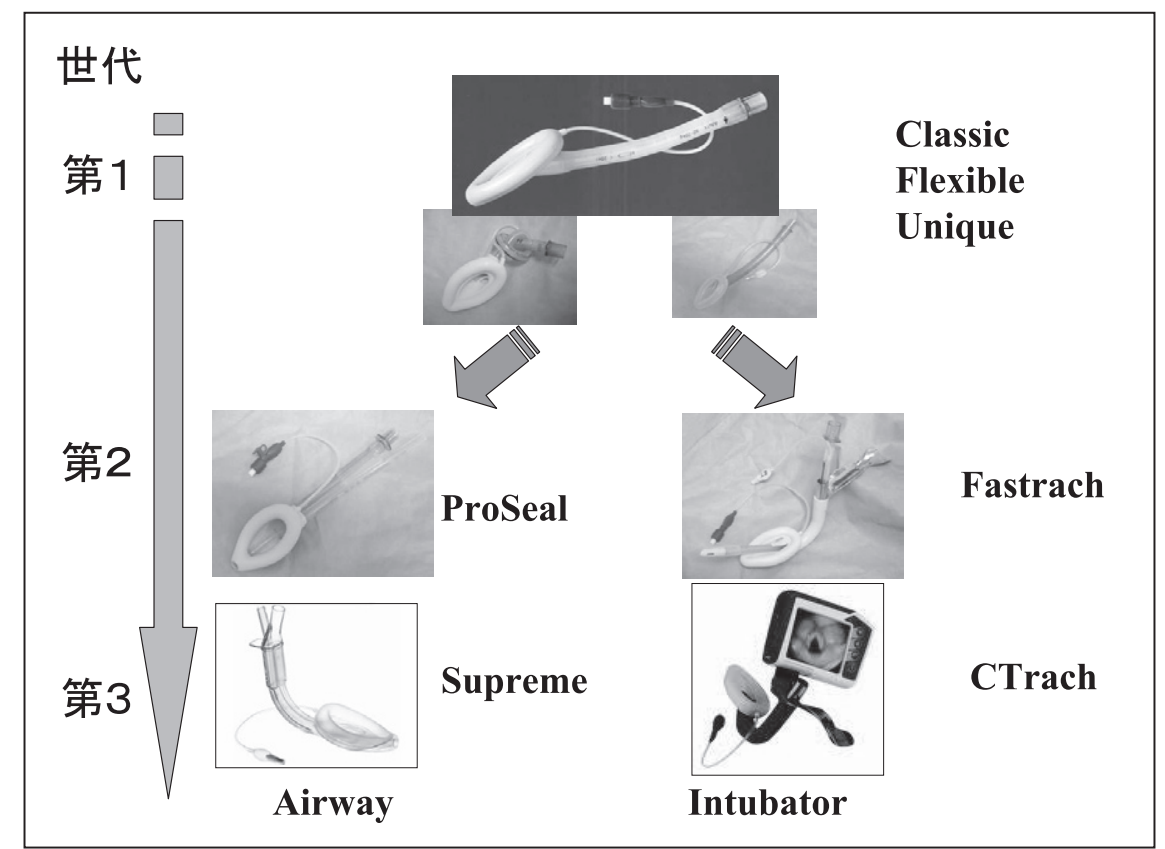

図14 LMAの発展

brief history of the invention, early clinical studies and experimental work from which the Laryngeal Mask evolved. Eur J Anaesthesiol Suppl 4 : 5-17, 1991

3) Braude N, Clements EA, Hodges UM, et al. : The pressor response and laryngeal mask insertion. A comparison with tracheal intubation. Anaesthesia 44 : 551-554, 1989

4) Brain AI : The laryngeal mask airway--a possible new solution to airway problems in the emergency situation. Arch Emerg Med 1 : 229-232, 1984

5) Brain AI : Three cases of difficult intubation overcome by the laryngeal mask airway. Anaesthesia $40: 353-$ 355, 1985

6) Brimacombe JR : Laryngeal Mask Anesthesia : Principle and Practice, 2nd ed. WB Saunders, London, 2005

7) Benumof JL : Management of the difficult adult airway. With special emphasis on awake tracheal intubation. Anesthesiology 75 : 1087-1110, 1991

8) Practice guidelines for management of the difficult airway. A report by the American Society of Anesthesiologists Task Force on Management of the Difficult Airway. Anesthesiology 78 : 597-602, 1993

9) Benumof JL : Laryngeal mask airway and the ASA difficult airway algorithm. Anesthesiology $84: 686-699$, 1996

10) American Society of Anesthesiologists Task Force on
Management of the Difficult Airway : Practice guidelines for management of the difficult airway : an updated report by the American Society of Anesthesiologists Task Force on Management of the Difficult Airway. Anesthesiology 98 : 1269-1277, 2003

11) Henderson JJ, Popat MT, Latto IP, et al. ; Difficult Airway Society : Difficult Airway Society guidelines for management of the unanticipated difficult intubation. Anaesthesia $59:$ 675-694, 2004

12) Heidegger T, Gerig HJ, Henderson JJ : Strategies and algorithms for management of the difficult airway. Best Pract Res Clin Anaesthesiol 19 : 661-674, 2005

13）岡本浩嗣, 村島浩二編：確実にできる！ ラリンジアル マスク。羊土社, 東京, 2009

14) Brimacombe J, Berry A : The flexible, reinforced tube LMA--initial experience. Anaesth Intensive Care 21 : 379, 1993

15) Verghese C, Berlet J, Kapila A, et al. : Clinical assessment of the single use laryngeal mask airway--the LMA-unique. Br J Anaesth 80 : 677-679, 1998

16) Brain AI, Verghese C, Addy EV, et al. : The intubating laryngeal mask. I : Development of a new device for intubation of the trachea. Br J Anaesth $79: 699$ 703, 1997

17) Brain AI, Verghese C, Strube PJ : The LMA 'ProSeal' --a laryngeal mask with an oesophageal vent. Br J 
Anaesth $84: 650-654,2000$

18) Eschertzhuber S, Brimacombe J, Hohlrieder M, et al. : The laryngeal mask airway Supreme--a single use laryngeal mask airway with an oesophageal vent. A randomised, cross-over study with the laryngeal mask airway ProSeal in paralysed, anaesthetised patients. Anaesthesia $64:$ 79-83, 2009

19) Timmermann A, Russo S, Graf BM : Evaluation of the CTrach--an intubating LMA with integrated fibreoptic system. Br J Anaesth 96 : 516-521, 2006

\title{
Difficult Airway Management and Laryngeal Mask Airway
}

\author{
Koji MURASHIMA \\ Department of Anesthesiology, Nippon Steel Hirohata Hospital
}

Airway management has been developed with face mask ventilation and tracheal intubation. A quarter of a century has passed since LMA (Laryngeal Mask Airway) was put on the market. LMA has become indispensable in difficult airway management(DAM). At first, LMA was invented aiming at ease of use and minimal invasiveness. However, usefulness in DAM was gradually recognize with a lot of case reports and clinical studies. These three characteristics of LMA gradually became clear. And LMA evolved from LMA Classic(first generation) to Intubating LMA and LMA ProSeal(second generation), and then to LMA Supreme (third generation).

Key Words : DAM, LMA, Device variation, LMA ProSeal, LMA Supreme

The Journal of Japan Society for Clinical Anesthesia Vol.30 No.4, 2010 